\title{
A cross-genus comparison of grazing pressure by two native marine herbivores on native, non-native naturalized, and non-native invasive Sargassum macroalgae
}

\author{
Nikolas J. Kaplanis ${ }^{1,2^{*}} \mathbb{D}$, Jill L. Harris ${ }^{1} \mathbb{D}$ and Jennifer E. Smith ${ }^{1}$
}

\begin{abstract}
In marine systems, algal abundance and community composition is often heavily influenced by top-down control by herbivores. As a result, examining the extent to which native herbivores exert grazing pressure on non-native marine algae can provide valuable insight into mechanisms controlling invasion success. The purpose of this study was to examine the grazing preferences of two common intertidal and subtidal herbivores on three congeneric species of marine algae with unique colonization histories in San Diego, California, USA, to determine if grazing pressure, or lack thereof, may help explain invasion success. We provide evidence that neither native Sargassum agardhianum, nor non-native Sargassum horneri, are particularly palatable to purple urchins or black turban snails, but that non-native Sargassum muticum is consumed by both native herbivores. We also provide evidence that when given a choice of all three species neither herbivore exhibits a significant grazing preference for any algal species. We suggest that other mechanisms may determine the invasion success of the two non-native algal species and the overall distribution and abundance patterns of these species, and we discuss potential directions for future work.
\end{abstract}

Keywords: Invasive algae, Grazing assay, California, Macroalgae, Sargassum

\section{Background}

Numerous hypotheses have been posed and tested to explain how interactions between native and non-native species regulate biological invasions. According to the Enemy Release Hypothesis, a lack of regulation of introduced species by native enemies can directly facilitate invasion [1,2]. Experiments testing this hypothesis have produced variable results depending upon the type of enemy regulation examined (e.g. predation versus parasitism), study species, stage of invasion, and experimental design [1,3-6]. A number of studies conducted in marine systems suggest that reduced grazing pressure by

\footnotetext{
*Correspondence: nkaplanis@ucsc.edu

2 Department of Ecology and Evolutionary Biology, University of California, Santa Cruz, Santa Cruz, CA, USA

Full list of author information is available at the end of the article
}

native herbivores may facilitate the invasion of marine algae [7-9]. On the contrary, according to the New Associations or Increased Susceptibility Hypothesis, a lack of evolved defenses can result in an increased susceptibility of non-native species to regulation by native species that can inhibit their widespread invasion [3, 4, 10]. Examining grazing preference through grazing assay experiments can help determine if either of these mechanisms may influence the biotic resistance of host ecosystems and thus the invasion success of non-native species.

\section{History of Sargassum spp. in southern California}

San Diego, California, USA provides a unique opportunity to test these two competing hypotheses through examining the influence of grazing pressure and preferences of native marine herbivores on the invasion success of non-native seaweed species. Three congeneric species 
of Sargassum seaweeds with unique histories of colonization can be found along this coastline: Sargassum agardhianum, Sargassum muticum, and Sargassum horneri. Sargassum agardhianum is native to southern California, and can be found throughout San Diego County in low density patches on intertidal and shallow subtidal reefs that experience a range of wave exposures [11-13]. Sargassum muticum was introduced to North America from Northeast Asia in the early 20th Century and quickly spread throughout the west coast, reaching southern California in the early 1970 s $[11,14,15]$. As is the case in locations around the globe, S. muticum has been a highly successful invader in southern California. It is now a common component of intertidal and subtidal communities along this coast, and is therefore considered a non-native naturalized species $[13,14,16-18]$. The nonnative invasive $S$. horneri was first discovered in southern California in Long Beach Harbor in 2003, the first documentation of this species outside of its native range [17]. Sargassum horneri has since spread rapidly throughout southern California and down the coast of Baja California, México, forming invasive high-density stands in a variety of locations $[13,15,18-24]$. This species was first noted in San Diego County in 2007, and an in-depth survey of the coastline between 2012 and 2014 revealed its presence at nine locations [13].

\section{Past work on grazing and invasion in Sargassum spp.}

The role of herbivore grazing on the invasion success of Sargassum species has been explored in multiple instances and locations. It has been suggested that grazing preferences of macro- and mesoherbivores may provide a competitive advantage to non-native $S$. muticum in Portugal and Spain [8, 25, 26]. Schwartz et al. [27] similarly found that North Sea mesograzers exhibited a grazing preference for native Fucus vesiculosus over nonnative $S$. muticum (introduced to the North Sea), and $S$. fusiforme and S. horneri (native to Japan, but not present in the North Sea), suggesting that Enemy Release may contribute to invasion success in this location. In contrast, in Washington, USA, it was found that native herbivorous snails exert significant grazing pressure on non-native $S$. muticum [28], suggesting Increased Susceptibility may be a regulating mechanism. A meta-analysis paired with an experimental study from Denmark also suggests that it is unlikely that the Enemy Release Hypothesis is generally a suitable explanation for the invasion potential of this alga [6].

Little information exists on the grazing susceptibility of $S$. horneri but, in a recent study, Marks et al. compared the grazing rates of native herbivores on $S$. horneri to its native and introduced congeners S. palmeri and S. muticum, as well as to native Macrocystis pyrifera and Eisenia arborea, at Santa Catalina Island in southern California. This study found that grazing rates were significantly higher on the two native kelps than on any of the Sargassum species, and the authors concluded that this reduced palatability may contribute to the invasion success of $S$. horneri at this location [29]. In another study, Caselle et al. suggest that the invasion success of $S$. horneri at Santa Catalina Island has likely been influenced by variable grazing pressure exerted by purple urchins [30]. They hypothesize that at high densities, purple urchins (Strongylocentrotus purpuratus) graze algal species indiscriminately and thus may inhibit invasion success, at intermediate densities preferential herbivory on native algae may facilitate invasion of S. horneri, and at low densities, any grazing pressure may be too weak to reduce the competitive advantage of native algae. Beyond these examples, the consequences of grazing preference on the invasion success of this alga have not, to the authors' knowledge, been explored.

The general goal of this study was to provide information on the potential regulating roles of two abundant herbivores on the invasion success of the non-native naturalized alga $S$. muticum and the non-native invasive S. horneri. First, a single-choice grazing assay was conducted with two abundant generalist southern California herbivores-the black turban snail Tegula funebralis, and the purple urchin Strongylocentrotus purpuratus-to determine if these algae were palatable to native herbivores, and to compare grazing rates on these algae when offered individually. Then, to determine if native herbivores prefer the native, naturalized, or invasive Sargassum species, grazing preferences were assessed in a multiple-choice feeding assay with all three Sargassum species offered simultaneously. Our results are discussed in the context of two competing hypotheses on the regulating role of native herbivores on biological invasions. We hypothesized that if Enemy Release is a regulating mechanism in this system, then native herbivores will exhibit a grazing preference for native over naturalized and non-native Sargassum. If Increased Susceptibility exists, then the order of palatability and preference will be the opposite. Alternatively, if no grazing or preference is apparent, then the results will be inconclusive regarding these mechanisms, and other mechanisms may be more important in determining invasion success in this system.

\section{Materials and methods} Experimental design

Single-choice grazing assays, where Strongylocentrotus purpuratus and Tegula funebralis were presented with the three Sargassum species separately, were run to determine if the herbivores would consume the algal species if 
given no other choice. These single-choice experiments were also used to determine if differences existed in the consumption of these algal species by each herbivore species when presented individually. The results of the single-choice assay were then used to inform our interpretation of the results of subsequent multiple-choice assays [31]. In these multiple-choice assays, herbivores were presented all three algal species simultaneously to evaluate relative preferences for or against the seaweed species. Here, preference was defined as a deviation by the herbivores in grazing behavior when confronted with a choice (multiple-choice assay), as compared to their behavior when given no choice (single-choice assay).

Assays were conducted at the Scripps Institution of Oceanography (La Jolla, CA, USA) in August-November 2014 in flow through aquaria (2L glass jars). Aquaria were supplied a continuous flow of ambient seawater and air, and placed under LED lights with a light-dark cycle set to match the local sunrise-sunset schedule. Seawater was pumped directly from the Scripps Pier to ensure aquaria matched ambient temperature and nutrient conditions of nearshore shallow subtidal waters. Assays consisted of aquaria in both a treatment (algae + herbivore) and control (algae, no herbivore) arena. There were equal numbers of replicates in the treatment and control arenas to allow us to account for autogenic change in subsequent analyses [32, 33]. For both assay types (single and multiple-choice), 3 identical trials were run for each species of herbivore. In each trial in the single-choice assay there were $n=5$ treatment and $n=5$ control replicates for each algal species making a total of $\mathrm{n}=30$ aquaria per trial. There were $n=15$ total treatment and control replicates per algal species in each single-choice herbivore assay. For each trial in the multiple-choice assay there were $n=10$ treatment and $n=10$ control replicates, making a total of $n=20$ aquaria per trial. There were $n=30$ total treatment and control replicates per algal species in each multiple-choice herbivore assay (Additional file 1: Fig. S1).

Algae were collected and allowed to acclimate in aquaria for 4 days prior to the experimental run. Simultaneously, the two herbivores were collected and starved for 4 days. At the start of the acclimation period each alga was hand trimmed so that all algae offered were of similar size (approximately $20 \mathrm{~cm}$ long). All epibionts were then removed with a salt water rinse. At the beginning of the grazing period each alga was spun-dry in a salad spinner, then blotted dry, and dry weights were recorded. The base of each algal frond was attached to a stand and weighted to stay centered in the assay jars. Algae and herbivores were then placed in the aquaria, and a piece of clear plastic mesh $\left(1 \mathrm{~cm}^{2}\right)$ was attached to the rim of each jar using a rubber band to prevent algal fragments or herbivores from leaving the jars. After the 4 day grazing period, all algae were spun and blotted dry and final mass was recorded. New herbivores were used in each trial to ensure that grazing rates were not skewed by potential acclimation of individual grazers to specific trial species and conditions. Algae were discarded at the end of each trial period, and the herbivores were returned to their collection location.

\section{Statistical analysis}

To determine if grazing occurred in the single-choice assay, treatments and controls were compared for each algal species and each herbivore using a one-tailed two-sample $t$ test ( $\Delta$ mass treatment $<\Delta$ mass control). Change in algal mass was calculated as $\Delta$ mass $=$ postassay mass - pre-assay mass. Data from replicates where herbivores perished were discarded (one control and one treatment replicate in the single-choice Strongylocentrotus purpuratus assay on S. horneri). To determine if differences existed in the consumption of these algal species by each herbivore species when presented individually, one-way analysis of variance (ANOVA) was used with control-corrected values. Control corrected change in algal mass was calculated as: $\Delta$ mass $=-\left(\left(\mathrm{T}_{\mathrm{i}} \times \mathrm{C}_{\mathrm{f}} / \mathrm{C}_{\mathrm{i}}\right)-\right.$ $T_{f}$, where $T_{i}$ and $T_{f}$ are pre- and post-assay algal weights from treatment aquaria, and $\mathrm{C}_{\mathrm{i}}$ and $\mathrm{C}_{\mathrm{f}}$ are pre- and postassay algal weights from paired controls [8, 25, 34-36]. Data were checked for normality and homogeneity of variance, and it was determined that the assumptions of the tests were met.

We followed guidelines established by past studies to analyze multiple-choice assay results [8, 25, 34-36]. In the multiple-choice assay, change in algal mass in each replicate was control-corrected using the same formula outlined above. As treatments in multiple-choice assays lack independence, Friedman nonparametric tests of rank were used to test for statistically significant differences in change in mass [32, 33, 35, 36]. All statistical analyses were conducted using $\mathrm{R}$ [37].

\section{Species collections, and statement of human and animal rights}

All Sargassum, Tegula funebralis, and Strongylocentrotus purpuratus individuals were collected under permits issued by the California Department of Fish and Wildlife. The three species of Sargassum and the herbivore species were collected in the shallow subtidal (0-5 m depth) at two locations: Mission Point Park in Mission Bay (32 $45.725^{\prime} \mathrm{N}, 117^{\circ} 14.751^{\prime} \mathrm{W}$ ) and the Marine Room in La Jolla Cove $\left(32^{\circ} 51.047^{\prime} \mathrm{N}, 117^{\circ} 15.892^{\prime} \mathrm{W}\right)$. Collections were done on SCUBA by carefully scraping algae and plucking invertebrates from the bottom. All of the S. horneri, S. muticum, and herbivores were collected at 
Mission Point Park in Mission Bay, where both species were previously determined to be abundant [13]. Sargassum agardhianum was collected in La Jolla Cove.

\section{Results}

\section{Single-choice assay}

Results from the single-choice experiments suggested that $S$. muticum was the only algal species that experienced significant grazing. Results from t-tests comparing controls and treatments indicated that both Strongylocentrotus purpuratus and Tegula funebralis consumed statistically significant quantities of S. muticum (Fig. 1, asterisk, one-tailed two-sample t-test, $\mathrm{df}=28, \mathrm{t}=1.73$, $\mathrm{P}=0.04$, and $\mathrm{df}=28, \mathrm{t}=3.11, \mathrm{P}=0.002$, respectively). Comparing effect sizes (Cohen's d) across algal species, we can see that the effect of grazing by Strongylocentrotus purpuratus was intermediate on S. agardhianum $(\mathrm{d}=0.31)$, smallest on $S$. horneri $(\mathrm{d}=0.15)$, and largest on S. muticum $(\mathrm{d}=0.63)$. The effect of grazing by Tegula funebralis was smallest on S. agardhianum $(\mathrm{d}=0.06)$, intermediate on $S$. horneri $(\mathrm{d}=0.30)$, and largest on $S$. muticum $(\mathrm{d}=1.13)$.

Comparing control corrected change in mass in the single-choice experiment allowed us to determine whether grazing significantly differed across algal species (Fig. 2). Grazing rates were either near zero, or were low across all treatments. In all results, negative values indicate tissue loss, whereas positive values indicate growth. In the Strongylocentrotus purpuratus assay mean control corrected change in mass $( \pm S E)$ was $-0.08 \pm 0.08 \mathrm{~g}$ for $S$. agardhianum, $0.02 \pm 0.04 \mathrm{~g}$ for S. horneri, and $-0.07 \pm 0.05$ g for S. muticum (Fig. 2). In the Tegula funebralis assay mean control corrected change in mass $( \pm \mathrm{SE})$ was $-0.21 \pm 0.14 \mathrm{~g}$ for $S$. agardhianum, $-0.07 \pm 0.08 \mathrm{~g}$ for $S$. horneri, and $-0.44 \pm 0.14 \mathrm{~g}$ for S. muticum (Fig. 2). Results from one-way ANOVA indicated no significant difference in control corrected change in mass across algal species in either the Strongylocentrotus purpuratus or the Tegula funebralis arena $(\mathrm{df}=2, \mathrm{~F}=2.10, \mathrm{P}=0.13$, and $\mathrm{df}=2, \mathrm{~F}=0.76, \mathrm{P}=0.47$, respectively). Effect sizes for the differences in grazing across algal species were considered small and medium for Strongylocentrotus purpuratus and Tegula funebralis according to Cohen's $f(f=0.19$ and 0.30$)$.

\section{Multiple-choice assay}

In order to determine if a grazing preference for or against any algal species existed, we compared changes in mass of the three algal species in both herbivore arenas of the multiple-choice assay (Fig. 3). In the Strongylocentrotus purpuratus arena, mean control corrected change in mass $( \pm \mathrm{SE})$ was $0.15 \pm 0.07 \mathrm{~g}$ for $S$. agardhianum, $-0.01 \pm 0.03 \mathrm{~g}$ for $S$. horneri, and $-0.14 \pm 0.07 \mathrm{~g}$ for S. muticum (Fig. 3). In the Tegula funebralis arena, mean control corrected change in mass $( \pm S E)$ was $-0.10 \pm 0.07 \mathrm{~g}$ for S. agardhianum, $-0.12 \pm 0.03 \mathrm{~g}$ for
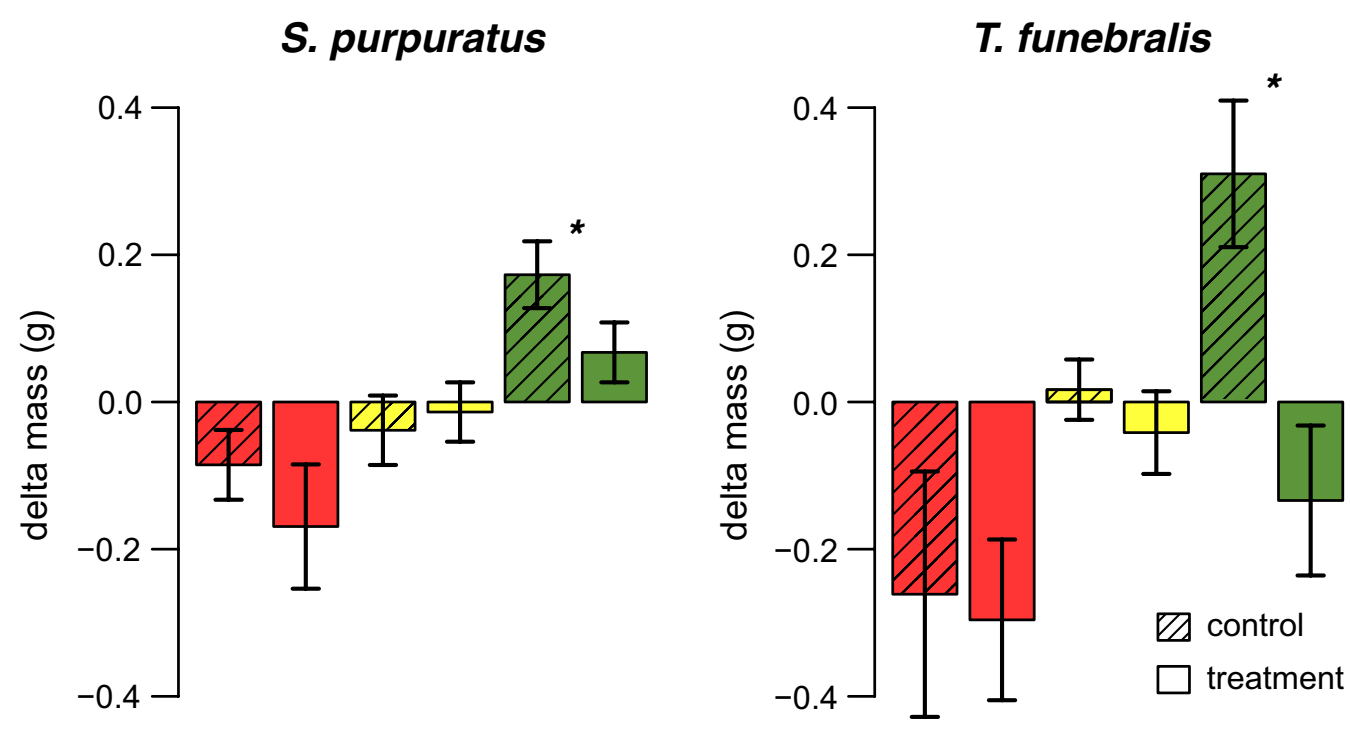

S. a. S. h. S. m.

S. a.

S. $\boldsymbol{h}$.

S. $\boldsymbol{m}$.

Fig. 1 Single-choice assay results. Mean change in mass ( \pm SE) for control (diagonal lines) and treatment (open) pairs of three algal species [S. agardhianum ( $n=15$, red), S. horneri ( $n=14,15$, yellow), S. muticum ( $n=15$, green)] offered to two grazers (Strongylocentrotus purpuratus and Tegula funebralis) 


\section{S. purpuratus}

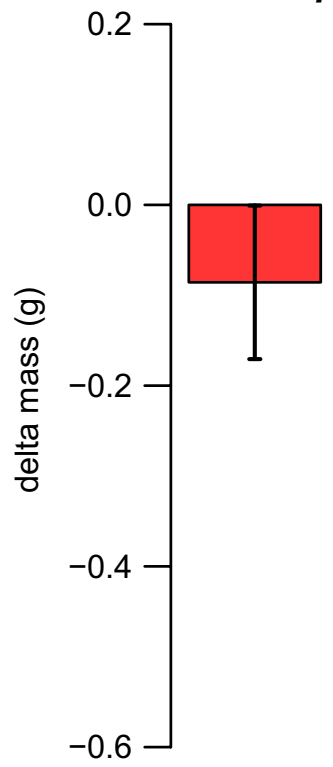

S. $a$.
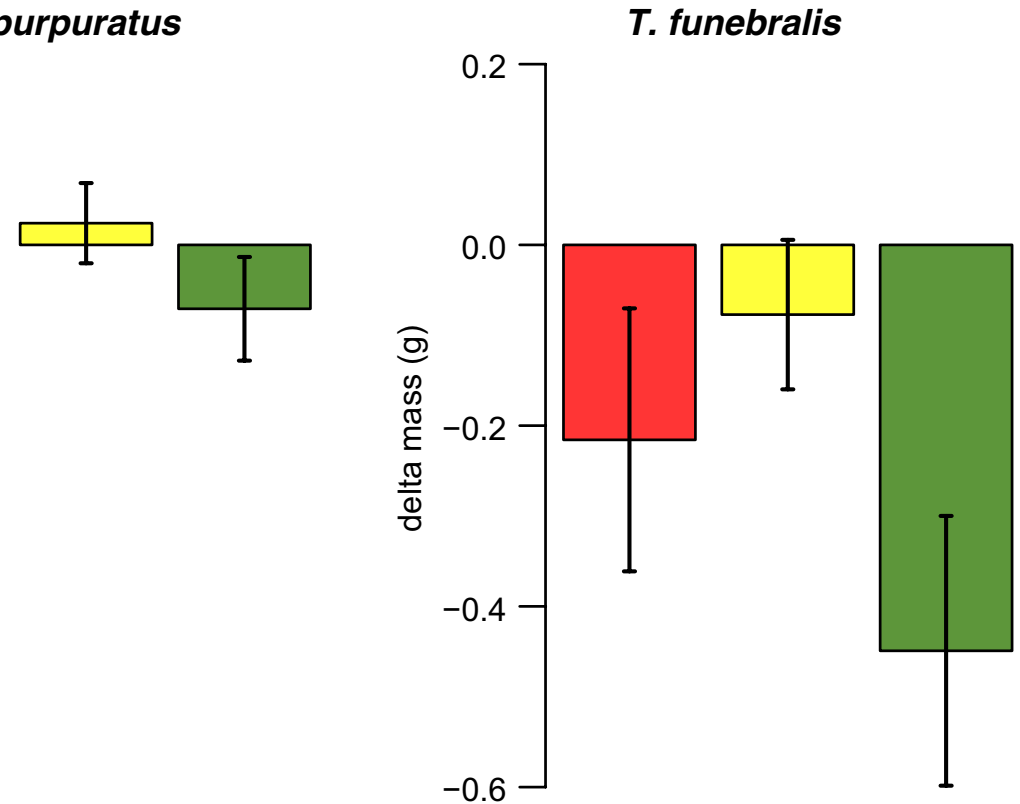

S. a.

S. $h$.

S. $\boldsymbol{m}$.

Fig. 2 Control corrected single-choice assay results. Mean control corrected change in mass ( \pm SE) for three algal species $[S$. agardhianum ( $n=15$, red), S. horneri ( $n=14,15$, yellow), S. muticum ( $n=15$, green)] offered to two grazers (Strongylocentrotus purpuratus and Tegula funebralis)
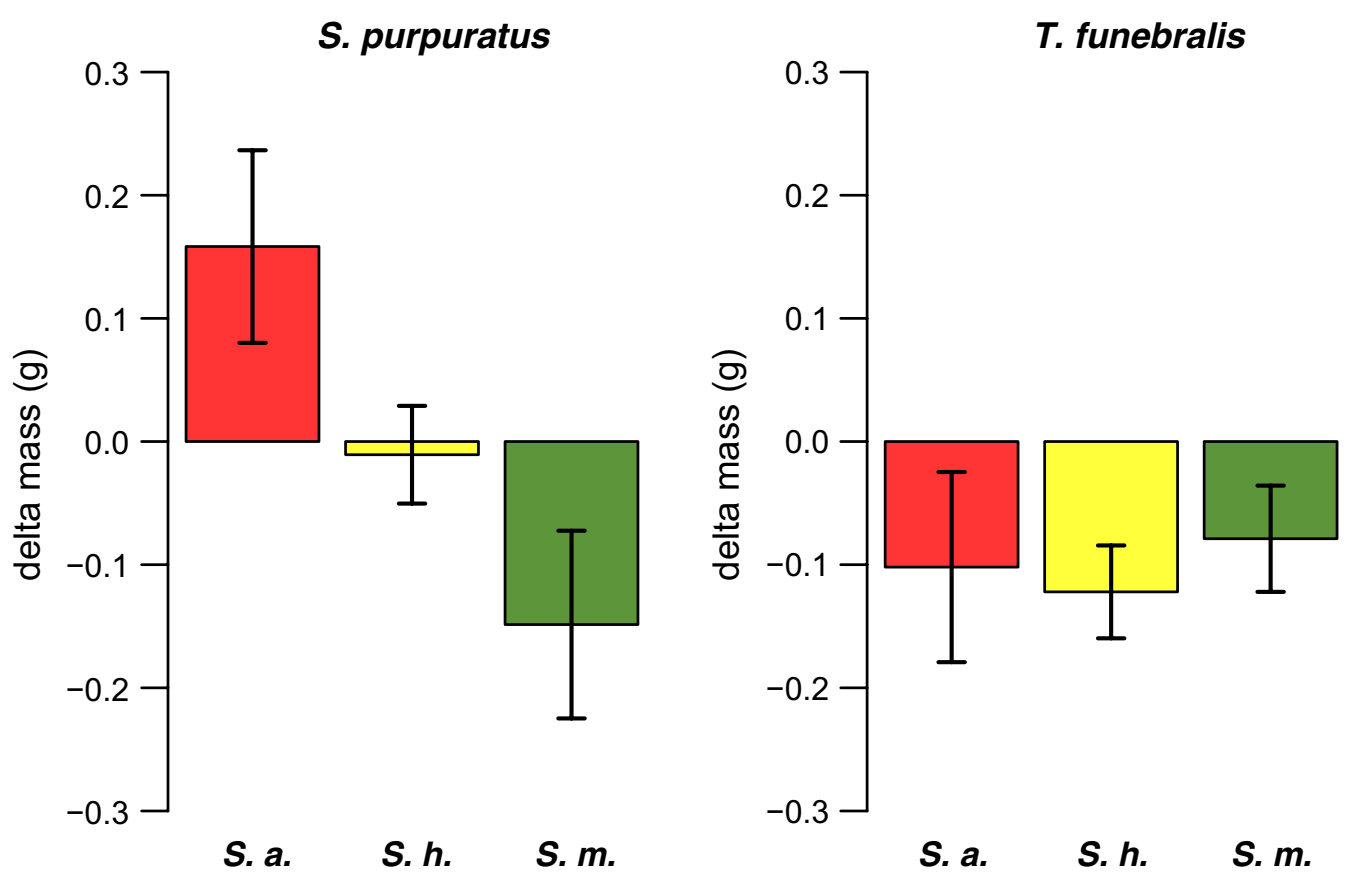

Fig. 3 Multiple-choice assay results. Mean change in mass ( $\pm \mathrm{SE}, n=30)$ for three algal species [S. agardhianum (red), S. horneri (yellow), S. muticum (green)] simultaneously offered to two herbivores (Strongylocentrotus purpuratus and Tegula funebralis)

S. horneri, and $-0.07 \pm 0.04 \mathrm{~g}$ for S. muticum (Fig. 3). No statistically significant preference by either herbivore was detected for or against any of the Sargassum species in our multiple-choice grazing assays (Friedman nonparametric test of rank, $\mathrm{df}=2$ and 2, Friedman Chi squared $=2.06$ and 1.40 , and $\mathrm{P}=0.35$ and 0.49 ). 


\section{Discussion}

In marine environments, herbivores can directly influence the invasion success of non-native algae in different ways: through providing a competitive advantage over native algae by releasing them from grazing pressure (Enemy Release, e.g. Monteiro et al. [8]) or through suppressing them by preferentially attacking non-natives with a lack of evolved defenses (New Associations, e.g. Pedersen et al. [6]). As a result, analyzing grazing rates and preferences can provide crucial insight into mechanisms influencing the invasion process of non-native marine algae. This study presents data on grazing behavior of two native herbivores on three species of Sargassum to test whether either hypothesis helps explain the invasion success of the Sargassum species in southern California.

Results from our single-choice assays suggest that only $S$. muticum was palatable to both herbivore species. But when comparing control-corrected change in mass across algal species we found no significant differences in consumption across taxa. As a result, both herbivores may exert some level of grazing pressure on this species, but the widespread success of S. muticum across the Pacific coast of North America suggests that this pressure has been insufficient to prevent invasion. However, given that $S$. muticum has been present along the Pacific coast for over 100 years, it is also possible that herbivores have over time shifted grazing preferences to include this species as one of their dietary items. It is possible that this species was not particularly palatable to native herbivores in early stages of invasion, as may be the case for S. horneri $[29,30]$. Enemy Release may also operate to some degree if grazing pressure on this alga is lower than on other native algal species not examined in this study. The observed lack of palatability of $S$. horneri suggests that the native herbivore species examined in this experiment may not exert significant grazing pressure on this alga, but this may change over time. Future studies should include more in situ manipulative experiments with a wider variety of algal taxa as well as grazer species to better examine variation in grazing pressure across taxa. Our findings may help to explain one mechanism that may affect the recent rapid spread of S. horneri within the southern California bight and on the coast of Baja California, but further work is needed.

Our multiple-choice assay results suggest that the herbivore species examined in this experiment exhibit no significant preference for or against any of these Sargassum species, as their behavior when presented each species individually was comparable to their behavior when all species were presented simultaneously. In neither instance was a significant difference in grazing across species detected. While not statistically significant,
Strongylocentrotus purpuratus did show a trend in preference with $S$. muticum being most preferred and S. horneri the least. Perhaps with a larger sample size these trends would become more apparent. Tegula funebralis however, showed no noticeable trend across species. Based upon our results, we were unable to determine whether grazing preference by these herbivores might influence colonization of this new invader on the CA coast. It is possible that a comparison including more native algal species would yield more informative results. Both the Increased Susceptibility and Enemy Release Hypotheses depend on the assumption that native invertebrates do eat the native algae. While Strongylocentrotus purpuratus is widely recognized as a voracious and undiscerning herbivore with the capacity to convert kelp forests along this coastline into barrens $[38,39]$, we were not able to show that this herbivore even consumes the native $S$. agardhianum. Tegula funebralis has also been shown to be a generalist herbivore [40], but past studies on its dietary preferences have not, to our knowledge, included S. agardhianum, and we were not able to demonstrate palatability of this species. Whether the observed lack of palatability of these Sargassum species may result from chemical defenses or their physical characteristics is unclear. The ability of chemical and physical features of algae to deter grazers has been demonstrated for a wide variety of marine algae, including other members of the genus Sargassum [41, 42]. In one study, it was suggested that secondary metabolites produced by non-native $S$. muticum could explain reduced palatability and thus invasion success, but more studies examining this mechanism are needed [27]. Future work can improve upon this study by conducting assays crossing more herbivore species and native and non-native algae to more broadly compare palatability and better evaluate the influence of grazing preferences on invasion success.

Demonstrating predator preference through assay experiments can be problematic, a topic that has been subject to much discussion and debate in the literature [31, 33, 43-48]. Though it is beyond the scope of this paper to comprehensively review these challenges, it is worth mentioning a few that are particularly relevant to seaweed grazing assays. In brief, it is crucial to provide a clear definition of what constitutes preference, as failing to do so can dramatically change the interpretation of results [31]. To address this, Underwood and Clarke proposed a two-stage experimental design that has subsequently been refined, in which prey items are first offered separately, then simultaneously, and the data from both stages are compared to determine if preferences exist [31, 44-46]. When designing assay experiments with prey such as algae that may grow or lose tissue during the experiment, one must 
also appropriately utilize controls so as to account for autogenic change unrelated to the action of the predator $[33,43,49]$. In addition, because prey items offered simultaneously do not necessarily constitute independent samples, statistical analyses must be carefully chosen [31, 33, 44, 45]. Future work aimed at demonstrating the influence of grazing preference on invasion success of seaweeds must proceed with careful consideration of these, and other, potential sources of bias.

We are at a critical time in history to study introduced macroalgae along the coast of California. The majority of non-native algal species introduced to this area have appeared in the past 30 years. Further, it has been speculated that environmental shifts associated with climate change, including increases in the frequency and intensity of ENSO events, may be making the California and Baja California coasts more susceptible to invasion by non-native algal species through creating more space and reducing natural resistance [15]. Some highly invasive species such as $S$. horneri are still in the early stages of their invasion history. These species provide an important opportunity to gain insight into the early stages of algal invasions. The widespread invasion success of S. muticum, recent rapid spread of $S$. horneri, and general potential for widespread ecological impacts associated with the spread of nonnative marine algae all suggest that further examining the underlying mechanisms that facilitate or inhibit the invasion of these species is valuable [50].

In a diverse community such as the kelp forests of southern California, a variety of biological characteristics-including the relative abundance, identity, and functional traits of both native algae and herbivores-can influence the biotic resistance of locations to invasion [51-53]. Our work highlights the interactions between only a few of many players in our local kelp forest communities. Future studies should examine the various ways in which native kelp forest ecosystems vary in their biotic resistance to highly successful and invasive species such as S. muticum and S. horneri. Doing so can inform how management strategies such as manual removal [54] or the establishment of limited take or no-take marine protected areas may mitigate the impacts of these invasive species [30]. Quantitative surveys complemented by lab experiments, and documenting the impacts of these species on recipient communities using in situ experiments are the next step in progressing our knowledge of the invasion ecology of these species [5]. Such research will provide information that can help inform management action to mitigate the ecological and economic impacts of these seaweeds in invaded areas around the world.

\section{Supplementary information}

Supplementary information accompanies this paper at https://doi. org/10.1186/s10152-020-00541-w.

Additional file 1: Figure S1. Schematic of experimental design for singlechoice and multiple-choice grazing assays.

\section{Acknowledgements}

We would like to thank G. Butler for assistance with collections, and D. Chargualaf, E. Miller, and M. Luna for their assistance with assay set-up, management, and data collection. In addition, we would like to thank Dr. P. Raimondi and Dr. A.J. Underwood for assistance with the analysis and interpretation of the results presented in this manuscript. We would also like to thank the anonymous reviewer for critical feedback that improved the content of this manuscript. We would also like to thank our funding sources, the Southern California Research Learning Center in partnership with the Santa Monica Mountains Fund, and the Ledell Family Endowed Research Scholarship for their generous financial support.

\section{Authors' contributions}

NJK, JLH, and JES conceived and designed this study, acquired, analyzed, and interpreted data, and wrote and edited this manuscript. All authors read and approved the final manuscript.

\section{Funding}

This work was funded by the Southern California Research Learning Center in partnership with the Santa Monica Mountains Fund, and the Ledell Family Endowed Research Scholarship. These funding bodies played no role in the design of the study, nor the collection, analysis, and interpretation of data, nor in writing this manuscript.

\section{Availability of data and materials}

The datasets used and/or analyzed during the current study are available from the corresponding author on reasonable request.

\section{Ethics approval and consent to participate}

This research complied with institutional guidelines for research involving animals, as well as fundamental principles outlined by the Basel Declaration.

\section{Consent for publication}

Not applicable.

\section{Competing interests}

The authors whose names are listed above declare that no conflicts of interest exist pertaining to this work.

\section{Author details}

${ }^{1}$ Center for Marine Biodiversity and Conservation, Scripps Institution of Oceanography, University of California, San Diego, La Jolla, CA, USA. ${ }^{2}$ Department of Ecology and Evolutionary Biology, University of California, Santa Cruz, Santa Cruz, CA, USA.

Received: 5 September 2019 Accepted: 5 August 2020

Published online: 12 August 2020

\section{References}

1. Keane RM, Crawley MJ. Exotic plant invasions and the enemy release hypothesis. Trends Ecol Evol. 2002;17(4):164-70.

2. Elton C. The ecology of invasion by plants and animals. Chicago: University of Chicago Press; 1958.

3. Grigorovich IA. Is invasion success explained by the enemy release hypothesis? Ecol Lett. 2004;7:721-33.

4. Parker JD, Hay ME. Biotic resistance to plant invasions? Native herbivores prefer non-native plants. Ecol Lett. 2005;8:5. 
5. Papacostas KJ, Rielly-Carroll EW, Georgian SE, Long DJ, Princiotta SD, Quattrini AM, et al. Biological mechanisms of marine invasions. Mar Ecol Prog Ser. 2017:565:251-68.

6. Pedersen MF, Johnsen $K L$, Halle LL, Karling ND, Salo T. Enemy release an unlikely explanation for the invasive potential of the brown alga Sargassum muticum: experimental results, literature review and meta-analysis. Mar Biol. 2016;163(10):1-14.

7. Williams SL, Smith JE. A global review of the distribution, taxonomy, and impacts of introduced seaweeds. Ann Rev Ecol Evol Syst. 2007:38(1):327-59.

8. Monteiro CA, Engelen AH, Santos ROP. Macro- and mesoherbivores prefer native seaweeds over the invasive brown seaweed Sargassum muticum: a potential regulating role on invasions. Mar Biol. 2009;156(12):2505-15.

9. Smith JE. Algae. In: Simberloff D, Rejmanek M, editors. Encyclopedia of biological invasions. Berkeley and Los Angeles: University of California Press; 2011. p. 11-5.

10. Hokkanen HMT, Pimentel D. New associations in biological control: theory and practice. Can Entomol. 1989;121(10):829-40.

11. Abbott IA, Hollenberg GJ. Marine algae of California. Stanford: Stanford University Press; 1976. p. 1-827.

12. Stewart JG. Marine Algae and Seagrasses of San Diego County. La Jolla: California Sea Grant College; 1991. p. 197.

13. Kaplanis NJ, Harris JL, Smith JE. Distribution patterns of the non-native seaweeds Sargassum horneri (Turner) C. Agardh and Undaria pinnatifida (Harvey) Suringar on the San Diego and Pacific coast of North America. Aquat Invasions. 2016;11(2):111-24

14. Deysher $L$, Norton TA. Dispersal and Colonization in Sargassum muticum (Yendo) Fensholt. J Exp Mar Bio Ecol. 1982;56:179-95.

15. Miller KA, Aguilar-Rosas LE, Pedroche FF. A review of non-native seaweeds from California, USA and Baja California, Mexico = Reseña de algas marinas no nativas de California, EUA y Baja California, México. Hidrobiológica. 2011:21(3):365-79.

16. Harries DB, Harrow S, Wilson JR, Mair JM, Donnan DW. The establishment of the invasive alga Sargassum muticum on the west coast of Scotland: a preliminary assessment of community effects. J Mar Biol Assoc UK. 2007;87(05):1057-67.

17. Miller KA, Engle JM, Uwai S, Kawai H. First report of the Asian seaweed Sargassum filicinum Harvey (Fucales) in California, USA. Biol Invasions. 2007:9(5):609-13.

18. Marks LM, Salinas-ruiz P, Reed DC, Holbrook SJ, Culver CS, Engle JM, et al. Range expansion of a non-native, invasive macroalga Sargassum horneri (Turner) C. Agardh, 1820 in the eastern Pacific. Biolnvasions Rec. 2015;4(4):243-8.

19. Miller KA, Engle JM. The natural history of Undaria pinnatifida and Sargassum filicinum at the California channel islands: non-native seaweeds with different invasion styles. Proc Calif Islands Symp. 2009;131:40.

20. Aguilar-Rosas LE, Aguilar-Rosas R, Kawai H, Uwai S, Valenzuela-Espinoza E. New record of Sargassum filicinum Harvey (Fucales, Phaeophyceae) in the Pacific Coast of Mexico. Algae. 2007;22(1):17-21.

21. Aguilar-Rosas LE, Núñez-Cebrero F, Aguilar-Rosas CV. Introduced Marine Macroalgae in the Port of Ensenada, Baja California, Mexico: biological Contamination. Procedia Environ Sci. 2013;18(646):836-43.

22. Aguilar-Rosas, Luis Ernesto Pedroche FF, Zertuche-González JA. Algas marinas no nativas en la costa del Pacifico Mexicano. 2014. p. 220-30.

23. Riosmena-Rodríguez R, Boo GH, López-Vivas JM, Hernández-Velasco A, Sáenz-Arroyo A, Boo SM. The invasive seaweed Sargassum filicinum (Fucales, Phaeophyceae) is on the move along the Mexican Pacific coastline. Bot Mar. 2012;55(5):547-51.

24. Sullaway G, Edwards M. Impacts of the non-native alga Sargassum horneri on benthic community production in a California kelp forest. Mar Ecol Prog Ser. 2020;637:45-57.

25. Engelen AH, Henriques N, Monteiro C, Santos R. Mesograzers prefer mostly native seaweeds over the invasive brown seaweed Sargassum muticum. Hydrobiologia. 2011;669(1):157-65.

26. Cacabelos E, Olabarria $C$, Incera $M$, Troncoso JS. Do grazers prefer invasive seaweeds? J Exp Mar Bio Ecol. 2010;393(1-2):182-7.

27. Schwartz N, Rohde S, Hiromori S, Schupp PJ. Understanding the invasion success of Sargassum muticum: herbivore preferences for native and invasive Sargassum spp. Mar Biol. 2016;163(9):1-13.

28. Britton-Simmons KH, Pister B, Sánchez I, Okamoto D. Response of a native, herbivorous snail to the introduced seaweed Sargassum muticum. Hydrobiologia. 2011;661(1):187-96
29. Marks LM, Reed DC, Holbrook SJ. Niche complementarity and resistance to grazing promote the invasion success of sargassum horneri in North America. Diversity. 2020;12:2.

30. Caselle JE, Davis K, Marks LM. Marine management affects the invasion success of a non-native species in a temperate reef system in California, USA. Ecol Lett. 2018;21(1):43-53.

31. Underwood AJ, Clarke KR. Solving some statistical problems in analyses of experiments on choices of food and on associations with habitat. J Exp Mar Bio Ecol. 2005:318(2):227-37.

32. Peterson CH, Renaud PE. Analysis of feeding preference experiments. Oecologia. 1989;80(1):5.

33. Roa R. Design and analysis of multiple-choice feeding-preference experiments. Oecologia. 1992;89(4):509-15.

34. Sotka EE, Taylor RB, Hay ME. Tissue-specific induction of resistance to herbivores in a brown seaweed: the importance of direct grazing versus waterborne signals from grazed neighbors. J Exp Mar Bio Ecol. 2002;277(1):1-12.

35. Taylor RB, Brown PJ. Herbivory in the gammarid amphipod Aora typica: relationships between consumption rates, performance and abundance across ten seaweed species. Mar Biol. 2006;149(3):455-63.

36. Jiménez RS, Hepburn CD, Hyndes GA, McLeod RJ, Taylor RB, Hurd CL. Do native subtidal grazers eat the invasive kelp Undaria pinnatifida? Mar Biol. 2015;162(12):2521-6.

37. R: A language and environment for statistical computing. Vienna: R Foundation for Statistical Computing; 2018. https://www.r-project.org/.

38. North WJ, Pearse JS. Sea urchin population explosion in southern California coastal waters. Science. 1970;167(3915):209.

39. Graham MH. Effects of local deforestation on the diversity and structure of southern California giant kelp forest food webs. Ecosystems. 2004;7(4):341-57.

40. Steinberg PD. Feeding preferences of Tegula Funebralis and Chemical Defenses of Marine Brown Algae. Ecol Monogr. 1985;55(3):333-49.

41. Hay ME, Fenical W. Marine plant-herbivore interactions: the ecology of chemical defense. Ann Rev Ecol Syst. 1988;19:111-45.

42. Taylor R, Sotka E, Hay M. Tissue-specific induction of herbivore resistance: seaweed response to amphipod grazing. Oecologia. 2002;132(1):68-76.

43. Peterson $\mathrm{CH}$, Renaud PE. Analysis of feeding preference experiments. Oecologia. 1989;80(1):82-6.

44. Manly BFJ. On a proposed method for analysing experiments on food choice. J Exp Mar Biol Ecol. 2006;334(1):154-5.

45. Underwood AJ, Clarke KR. Response on a proposed method for analysing experiments on food choice. J Exp Mar Biol Ecol. 2006;335(1):151-3.

46. Taplin $\mathrm{RH}$. Experimental design and analysis to investigate predator preferences for prey. J Exp Mar Biol Ecol. 2007;344(1):116-22.

47. Manly BFJ. Comments on design and analysis of multiple-choice feedingpreference experiments. Oecologia. 1993;93(1):149-52.

48. Manly BF, Miller P, Cook LM. Analysis of a selective predation experiment. Am Nat. 1972;106(952):719-36.

49. Prince JS, LeBlanc WG, Maciá S. Design and analysis of multiple choice feeding preference data. Oecologia. 2004;138(1):1-4.

50. Schaffelke B, Hewitt CL. Impacts of introduced seaweeds. Seaweed Invasions A Synth Ecol Econ Leg Imp. 2008;72:77-97.

51. Arenas F, Sánchez I, Hawkins SJ, Jenkins SR, Hawkins J. The invasibility of marine algal assemblages: role of functional diversity and identity. Ecology. 2006;87(11):2851-61.

52. Britton-Simmons $\mathrm{KH}$. Functional group diversity, resource preemption and the genesis of invasion resistance in a community of marine algae. Oikos. 2006;113(3):395-401.

53. Bulleri F, Tamburello L, Benedetti-Cecchi L. Loss of consumers alters the effects of resident assemblages on the local spread of an introduced macroalga. Oikos. 2009;118(2):269-79.

54. Marks L, Reed D, Obaza A. Assessment of control methods for the invasive seaweed Sargassum horneri in California, USA. Manag Biol Invasions. 2017:8(2):205-13.

\section{Publisher's Note}

Springer Nature remains neutral with regard to jurisdictional claims in published maps and institutional affiliations. 